\title{
The Effect of High Ambient Temperature \\ on Matrix-induced Endochondral \\ Bone Formation in Rats
}

\author{
Tomoyuki Kawashima, Tohru Matsur ${ }^{*}$ and Hideo Yano \\ Faculty of Agriculture, Kyoto University, Kyoto-shi 606 \\ *Faculty of Agriculture, Shimane University, Matsue-shi 690
}

(Received June 30, 1987)

\begin{abstract}
The effect of heat exposure on matrix-induced endochondral bone formation was examined in rats. Wistar strain male rats aged 7 weeks were divided into 2 groups and placed in a temperature controlled room; ambient temperature $24^{\circ} \mathrm{C}$ (group $\mathrm{C}$ ) and $34^{\circ} \mathrm{C}$ (group H). The animals in both groups were given the same amount of feed. Demineralized bone matrix, prepared from the diaphysis of rat tibia and femur, was intramuscularly implanted into abdominal site of experimental animals. The plaques were harvested on day 7,14 and 21 after the implantation. They were histologically observed and measured enzyme activities and $\mathrm{Ca}$ contents.

Alkaline phosphatase activities in the plaques tended to be lower in group $\mathrm{H}$ than in group $\mathrm{C}$ on day 14 and 21. Acid phosphatase activities were lower in group $\mathrm{H}$ than in group $\mathrm{C}$ throughout the experimental period. These changes suggested that bone mineralization and resorption might be reduced at high ambient temperature. It was shown histologically that bone marrow formation was retarded though the induction of chondrocyte was not influenced by heat exposure. The retardation of bone marrow formation in hot environment might be owing to the depressed bone remodeling because alkaline and acid phosphatase activities in the plaques tended to be suppressed by heat exposure.

Jpn. J. Zootech. Sci., 59 (2):161-166, 1988

Key words : chondrogenesis, osteogenesis, high temperature, alkaline phosphatase, acid phosphatase.
\end{abstract}

It was reported in pig that the extremities became longer in warm temperature than in cold temperature ${ }^{1)}$. The previous report ${ }^{21}$ showed that the femur in rats reared at high ambient temperature became thinner and lighter than the femur at control temperature.

The elongation of long bone is mediated by endochondral ossification in the epiphyseal growth plate. Endochondral bone formation consists of cellular proliferation, differentiation, hypertrophy, and calcification. These stages occur simultaneously in the epiphyseal growth plate. Therefore it is difficult to dissect a distinct stage of endochondral bone formation.

The utilization of demineralized bone matrix-induced bone formation method can circumvent these difficulties and afford to conduct biochemical and morphological examinations of the sequential phases of endochondral bone formation ${ }^{3,4}$. After the 


\section{KaWAShima, Matsui and Yano}

implantation of demineralized diaphyseal bone matrix, chondrogenesis was found on day 7 and followed by ossification. Bone remodeling and bone marrow development were found on days $14-21^{3 \text { ? }}$.

This study was conducted to make clear the effect of heat exposure on endochondral bone formation by using the demineralized bone matrix-induced endochondral bone formation method.

\section{Materials and Methods}

Twenty-four Wistar strain male rats aged 7 weeks were divided into 2 groups; comfortable environment group (abbreviated to group C) which were kept at $24^{\circ} \mathrm{C}$, and hot environment group (group H) which were kept at $34^{\circ} \mathrm{C}$. After 10 days for acclimatization, $10 \mathrm{mg}$ demineralized bone matrix was intramuscularly implanted into 3 places of abdominal site. The animals in both groups were caged individualy with the condition of 12 hours light from $6: 00 \mathrm{a} . \mathrm{m}$. and given $11 \mathrm{~g}$ of commercial feed which is near the amount of ad libitum feeding at $34^{\circ} \mathrm{C}$. Water was available at all times. The plaques were harvested on day 7, 14 and 21 . The 3 plaques from every animal at each stage were histologically observed, and measured enzyme activities and $\mathrm{Ca}$ contents.

The preparation of demineralized bone matrix was done as the following process. The femur and the tibia of Wistar strain adult rats of both sexes were used. The epiphysis and marrow of bone were discarded. The diaphyses were washed with water for $2 \mathrm{hrs}$, with absolute ethanol for $1 \mathrm{hr}$, and with ethyl ether for $0.5 \mathrm{hr}$ in this order. Dried diaphyses were crushed with hammer and sieved. The powders having particle size 74-420 $\mu \mathrm{m}$ were demineralized as follows ; $0.5 \mathrm{~N} \mathrm{HCl}$ for $3 \mathrm{hrs}$, repeated changes of water for $2 \mathrm{hrs}$, absolute ethanol $1 \mathrm{hr}$ and ethyl ether for $0.5 \mathrm{hr}$. Then the powder was dried at room temperature ${ }^{4}$.

In order to observe histologically, the plaques were fixed in Bouin's fluid and embedded in paraffin. Sections were stained with hematoxylin and eosin.

A wet-ashing method was used for the determination of $\mathrm{Ca}$ contents in plaques. The plaques were digested with concentrated nitric acid and perchloric acid. Aliquots of the digests were analyzed $\mathrm{Ca}$ content by an atomic absorption spectrophotometry.

In order to measure enzyme activities, the plaques were homogenized in saline with a homogenizer (Biotron, Biotrona in Switzerland). After centrifugation of the homogenate, alkaline phosphatase activities in supernatant were analyzed by the method of Bessey et al. ${ }^{5)}$, acid phosphatase activities by that of Lowry et al. ${ }^{6)}$ and protein contents by that of Lowry et al. ${ }^{7)}$.

\section{Results}

Histological changes in the plaques implanted intramuscularly to the rat kept at $24^{\circ} \mathrm{C}$ are shown in Figs. 1-1, 1-2 and 1-3. As same as the previous report ${ }^{3)}$, chondrogenesis, bone remodeling, and bone marrow formation were observed on day 7,14 and 21 respectively in the present experiment. 
Matrix-induced Bone Formation in Hot Environment

The number of chondrocyte was calculated in 3 sections of each plaque on day 7 . The average number of chondrocyte in the plaques of group $\mathrm{C}$ was $52 \pm 24$ (mean \pm standard error) and that of group $\mathrm{H}$ was $43 \pm 21$. There was no significant difference in the number of chondrocyte induced by demineralized bone matrix between two groups.

On day 21, the formation of bone marrow was more distinct and expanded in the
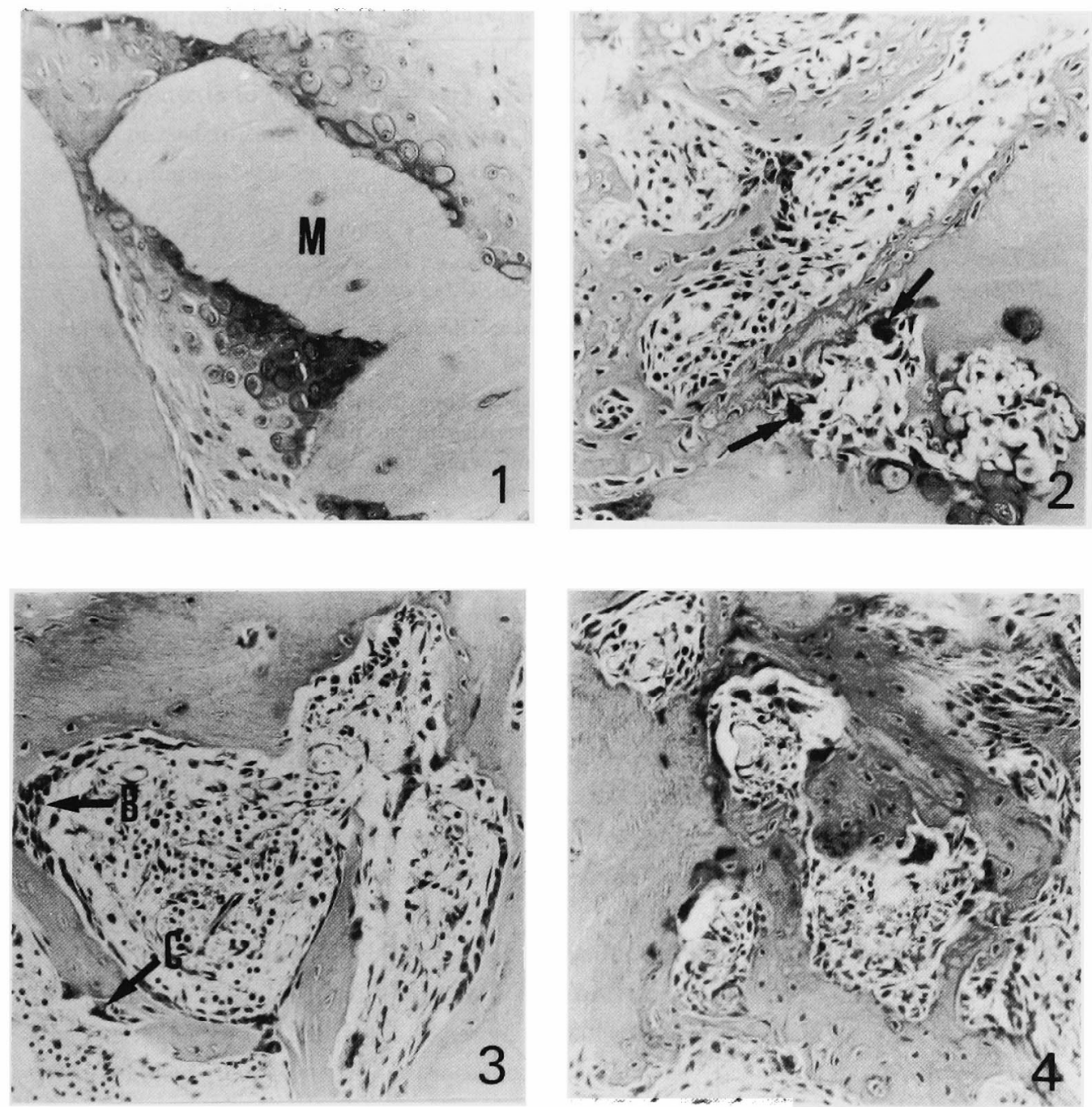

Fig. 1. Photomicrogrpaphs of the plaques during various stages of matrix-induced endochondral bone formation. $\times 180$.

Paraffin sections stained with hematoxylin and eosin. 1) Day 7 , group C. Chondrocytes in close apposition to the implanted matrix (M). 2) Day 14, group C. Observe bone remodeling and multinucleated osteoclast (arrows). 3) Day 21, group C. Observe bone marrow formation, osteoblast (arrow B) and osteoclast (arrows C). 4) Day 21, group H. Note the less expansion of bone marrow formation. 

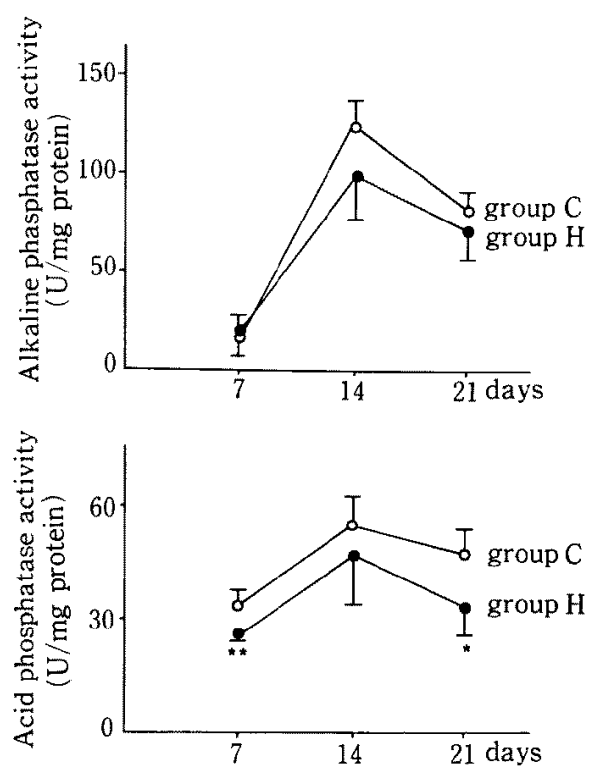

Fig. 2. Effect of heat exposure on alkaline and acid phosphatase activities in the plaques on days 7,14 and 21 following bone matrix implantation.

Enzyme activities are expressed in $\mathrm{mM}$ substrate utilized per $\mathrm{mg}$ soluble protein per hour at $37^{\circ} \mathrm{C}$. All values are means \pm standard errors for 4 rats. ${ }^{*}$ : The symbol represents a significant difference from group $C(p<0.05)$. ${ }^{* *}$ : The symbol represents a significant difference from group $C(p<0.01)$.

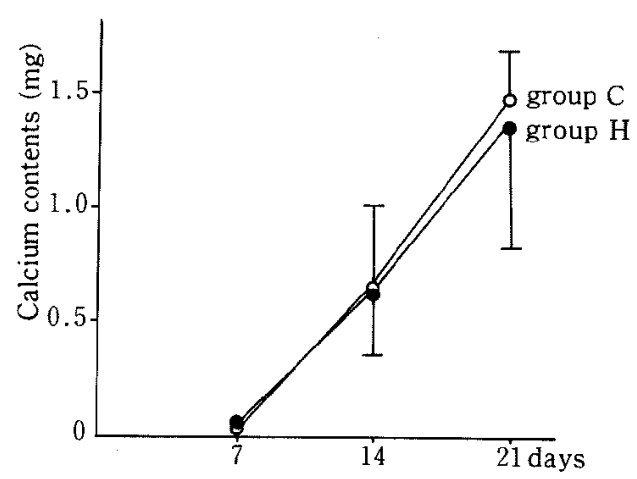

Fig. 3. Effect of heat exposure on calcium contents in plaques on days 7,14 and 21 following bone matrix implantation. All values are means \pm standard errors for 4 rats. 


\section{Matrix-induced Bone Formation in Hot Environment}

plaques of group $\mathrm{C}$ while limited to the small area in those of group H (Fig. 1-4).

Alkaline and acid phosphatase activities in soluble fraction of plaque homogenate were presented as the ratio of soluble protein (Fig. 2). Alkaline phosphatase activities were highest on day 14 in both groups. Although there was no significant difference, alkaline phosphatase activities tended to be lower in group $\mathrm{H}$ than in group $\mathrm{C}$. Acid phosphatase activities were also highest on day 14 in both groups. Acid phosphatase activities in group $\mathrm{H}$ tended to be lower than in group $\mathrm{C}$ throughout the experimental period, and, on day 7 and 21 , the activities were significantly lower in group $\mathrm{H}$ than in group $C$.

$\mathrm{Ca}$ contents in plaques were very little until day 7 and then they increased lineally as day passed in both groups (Fig. 3). There was no significant difference in Ca contents in plaques between two groups throughout the experimental period.

\section{Discussion}

The induction of chondroblast might be scarcely influenced by hot environment because there was no significant difference in the number of chondrocyte in plaques between $\mathrm{C}$ and $\mathrm{H}$ group.

A number of studies indicated that alkaline phosphatase activities in skeleton were related to calcification and the growth of bone ${ }^{8-10)}$ and acid phosphatase was associated with bone resorption ${ }^{11}$. The acid phosphatase activities in the plaque on day 21 might be partly owing to the induction of cells in bone marrow which had acid phosphatase activities. However, considering from the reduced acid phosphatase activities on day 7 and 14 and reduced alkaline phosphatase activities on day 14 and 21 in the plaques of qroup $\mathrm{H}$, mineralization and bone resorption were thought to be suppressed by hot environment. The retardation of bone marrow formation in hot environment might be attribute to suppressed bone remodeling because bone remodeling was constituted by bone mineralization and resorption.

In spite of the suppression of bone mineralization in hot environment, $\mathrm{Ca}$ contents in plaques were not affected by high ambient temperature. A simultaneous reduction of bone mineralization and resorption might erase the effect of hot environment on $\mathrm{Ca}$ contents in plaques.

The reduced alkaline phosphatase activities in plaque by high ambient temperature might induce to retard endochondral bone formation. However it was reported that the long bone elongated in the pig kept at high ambient temperature ${ }^{1)}$. The effect of high ambient temperature on the endochondral bone formation might be different depending on the place in which the endochondral bone formation was induced. In this connection, further studies will be necessary to clarify the details.

The bone growth in width is mediated by the bone apposition in periosteal and might be related to the expansion of bone marrow. The retarded formation of bone marrow which was observed in the plaques of group $\mathrm{H}$ could support and explain the fact in a previous experiment that the bone growth in width had been retarded in rats reared under hot environment ${ }^{2}$. 


\section{Kawashima, Matsui and Yano}

\section{Acknowledgements}

Authors are grateful to Prof. Yukio Yamada and Prof. Ryoji Kawashima for their helpful suggestions and encouragements throughout this study.

This study was supported by a Grant-in-Aid for Scientific Research from the Ministry of Education, Science and Culture of Japan (No. 60560282).

\section{References}

1) Dauncey, M.J., and D.L. Ingram, J. Therm. Biol., 11:89-93. 1986.

2) Kawashima, T. and H. Yano, Mem. Coll. Agric., Kyoto Univ., $125: 59-69.1984$.

3) REDdi, A. H., in Bone and Mineral Research 3 (PECK, W.A. ed.) 27-47. Elsevier Science Publishers. Amsterdam. 1985.

4) Reddi, A.H. and C.B. Huggins, Proc. Nat. Acad. Sci. USA, 69: 1601-1605. 1972.

5) Bessey, O.T., O.H. Lowry and M.J. Brock, J. Biol. Chem. 164:321-329. 1946.

6) Lowry, O.H., N.R. Roberts, M.Wu, W.S. Hixon and E.J. CrawFord, J. Biol. Chem. $207: 19-37.1954$.

7) Lowry, O.H., N.J. Rosebrough, A.L. FarR and R.J. Randall, J. Biol. Chem. 193 : 265-275. 1951.

8) Salomon, C.D., Calcif. Tissue Res. 21 : 153-162. 1974.

9) Siffert, R.S., J. Exp. Med. 93: 415-426. 1951.

10) Jafre, N.R., Calcif. Tissue Res. $21: 153-162.1976$.

11) Hammarstrom, L.E. and G. Hasselgren, Scand. J. Dent. Res., 82 : 381-395. 1974.

\section{高温環境がラットにおける脱灰骨基質誘導性 軟骨内骨化に与える影響}

\section{川島知之・松井 徹*・矢野秀雄}

京都大学農学部, 京都市 606

*島根大学農学部, 松江市 690

高温環境がラットにおける脱灰骨基質誘導性軟骨内骨 化に与える影響について検討した．7週齢のウィスター 系雄ラットを 2 区に分け，環境温度が $24^{\circ} \mathrm{C}$ （C 区）上 34 ${ }^{\circ} \mathrm{C}$ (H区) の環境制御室内で同量の飼料に上り飼育し た、ラットの大腿骨と脛骨の骨幹部より作成した脱戻骨 基質を腹部の筋肉中に移植し，移植後，7，14，21 日目 に移植物を採取し，組織学的に観察するとともに酵素活 性とカルシウム含量を测定した.

H区のアルカリ性フォスファターゼ活性は14日と21日 目にC区より低い傾向を示し，酸性フォスファターゼ
活性は実験期間を通じて C 区より $\mathrm{H}$ 区が低い傾向を 示した。これらの酵素活性の変化から，高温環境により 骨の石灰化と骨吸収が抑制されたこ之が示唆された，組 織学的観察から，高温環境により軟骨細胞の誘導は影整 を受けないが骨䯣の形成が抑制されることが認められた， 移植物中のアルカリ性ならびに酸性フォスファターゼ落 性は高温環境により减少する傾向があり，骨髄形成の抑 制は骨のリモデリングが高温環境により㧕制されること 上関連すると考えられた。

日畜会報, 59 (2)：161-166,1988 